ECONOMICS

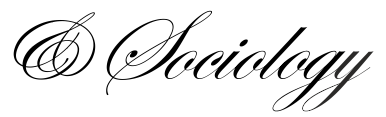

Izabela Jędrzejowska-

Schiffauer,

WSB University in Wrockaw,

Wrockaw, Poland,

E-mail:

izabela.schiffaner@wsb.wroclaw.pl

Received: February, 2017

1st Revision: March, 2017

Accepted: July, 2017

DOI: $10.14254 / 2071-$

789X.2017/10-3/17

\title{
MERE OBJECTIVES OR HARD LAW? A CASE STUDY ON THE EU'S SOCIAL POLICY IN THE CONTEXT OF FREE MARKET ECONOMY
}

\begin{abstract}
The purpose of this contribution is to assess the impact of the EU Internal Market rules on the development of Union's social policy. To that end the author analyses trends in the EU's social policy over time, also following the outbreak of the economic and financial crisis in 2008, synthesising selected Union's legislation, soft measures and case law relating to social policy, with a view to determining their immediate or potential impact on social rights and social protection. It is submitted that to date, the Union has made but a very restricted use of its powers to develop the social dimension of its Single Market, which contributes to the difficulties in reconciling social and labour rights with competition law and economic freedoms. This problem is ascribed not exclusively to the commonly blamed inequality of arms resulting from the prevalence of soft measures in the area of social policy and the hard law regulatory framework for the implementation of the Single Market rules. Its core is identified in the lack of will on the part of national governments to advance economic integration on common (European) social foundations. Hence the necessary prerequisite for the further advance of the EU social policy and a sustainable European socio-economic model is the attitude change in the Member States.
\end{abstract}

\begin{abstract}
JEL Classification: P48, H12， Keywords. EU social policy, social market economy, economic and $\mathrm{K} 20$, J80 financial crisis, national welfare system, EU socio-economic model.
\end{abstract}

\section{Introduction}

In Article 3 of the Treaty on European Union (TEU) the Union commits itself to combating social exclusion and discrimination as well as to promoting social justice. This does not change the fact, though, that the ability and/ or commitment to create a genuinely inclusive society varies considerably between the EU Member States (cf. e.g. Schraad-Tischler and Kroll, 2014). In the recent years the agenda of the Union's highest political body, the European Council, was dominated by the economic and financial crisis in a manner that somewhat marginalised the Union's social policy and social investment. The structural reforms and austerity policies pursued during the crisis with a view to stabilizing national economies and budgets have by and large produced an adverse effect on the implementation of social justice on the European continent, reducing the performance of national social security systems, thus 
aggravating social divide and letting youth unemployment grow to ever-new record heights. This development has inevitably posed a stress test for the credibility of Union's commitment to the promotion of social justice, internally and world-wide.

In order to critically assess whether the EU lives up to this challenge, it is necessary to analyse both the tools the Union has at its disposal as well as the manner they have been applied to date in pursuance of these aims. Whilst the main objective of this paper is to attempt to define the impact of the EU basic economic principles on its policy in social matters, the contribution also offers nuanced argumentation transgressing this thematic scope and suggesting pathways and opportunities for further research. The applied research methodology includes a combination of theoretical and analytical methods.

\section{The laborious development of the Union's social dimension}

In order to fully appreciate the state of the art in the EU's social policy of today, it is vital to be aware of its development in a diachronic perspective. At their very origins, the European communities (the European Coal and Steel Community as of 1952 and the European Economic Community (EEC) and the European Atomic Energy Community as of 1957) provided for merely economic integration and cooperation of the founding states. In time the said economic cooperation covered a broader scope of areas (the objective of achieving a single market, the development of environmental and energy policies as well as of measures leading to the Economic and Monetary Union) and it included more countries. Thus economic integration was a continuous driving force behind a process of Europe's political integration and it remains so also to date.

Prior to the Treaty of Maastricht which came into force on 1 November 1993, the European Economic Community's (EEC) legal framework for social policy was absolutely minimalist. Whilst Article 117 of the EEC Treaty provided for the necessity to improve working conditions and standards of living of workers, most relevant Community secondary legislation on employees' rights in the event of collective redundancies, transfer of undertakings and the employer's insolvency was enacted first after mid-1970s. ${ }^{1}$ Albeit the rule of equal pay for equal work of women and men was since the founding of the EEC enshrined in a directly applicable Treaty provision (Article 119 EEC), legislation implementing the principle of equal treatment of men and women in employment was adopted in 1975/76 only. ${ }^{2}$ The systems of social security remained (and still remain) on a strictly national basis. The access of nonnationals to such systems was and is governed by specific regulations and complemented by the non-discrimination rules. A certain turning point towards a more comprehensive approach consisted in the establishment of the Union citizenship by the Treaty of Maastricht, which facilitated judicial advance of social and labour rights. The Treaty provisions on Union citizenship imply for host Member States a need to show a certain degree of financial solidarity with the nationals of other Member States provided that they have established a "genuine or real link" with the society of the host Member State. This includes e.g. job-seekers whose link to the host State society is of an economic, albeit prospective, nature (Lenaerts, 2011, p. 418f).

The development of social policy under primary Community/Union law has required a continuous incremental process of consensus seeking with opposing national government leaders. At the time of the Treaty of Maastricht the reinforcement of the Treaty provisions on social policy could initially be introduced merely in the form of a Protocol applicable to all

\footnotetext{
${ }^{1}$ Council Directive 75/129/EEC, Council Directive 77/187/EEC and Council Directive 80/987/EEC, respectively, later amended and / or consolidated.

2 Council Directive 75/117/EEC and Council Directive 76/207/EEC, recast by Directive 2006/54/EC of the European Parliament and of the Council of 5 July 2006 on the implementation of the principle of equal opportunities and equal treatment of men and women in matters of employment and occupation, OJ L 204, 26.7.2006, pp. 23-36.
} 
Member States except the United Kingdom. Only subsequent to the elections held in this country in 1997 an agreement could be achieved to incorporate these provisions in the context of the Treaty of Amsterdam as a separate Title into the EU law applicable to all Member States.

Social policy as devised under the primary law currently in force is already a notable improvement in the social dimension of the Union. The Treaty of Lisbon, which came into force on 1 December 2009, recognises social values, clarifies and strengthens Union's social policy objectives as well as formulates new ones. The Union's general constitutional principles were established in the Treaty on European Union (TEU), Article 3(3) of which refers for the first time to the concept of a social market economy, aiming at inter alia full employment, social progress, promoting social cohesion, social justice and social protection, as well as combating social exclusion. The operational rules for the Union's policies are laid down in the Treaty on the Functioning of the European Union (TFEU), Article 9 of which endorses a horizontal social clause whereby the Union, when defining and implementing its policies, shall take into account requirements linked to the promotion of a high level of employment, the guarantee of adequate social protection, combating social exclusion, and a high level of education, training and protection of human health. Furthermore, Article 152 TFEU establishes the role and contribution of social partners in the EU through social dialogue organised in the form of the Tripartite Social Summit for Growth and Employment, which brings together representatives from the Council, the Commission and social partners. ${ }^{3}$

A question arises whether the shift of discourse attempting to give the Union a more social dimension is reflected by the corresponding substantive change? With hindsight it may be clearly observed that it is not quite the case. The entry into force of the Treaty of Lisbon was preceded by the outbreak of the economic and financial crisis of 2008, thus pushing the EU and its Member States on the course of fiscal discipline and economic austerity, whereby the trend of dismantling social welfare, already visible in some European states since the 1990s, was further accelerated.

\section{Social policy under stress in the times of crisis}

The economic and financial crisis created the pressing need to take political action in order to maintain the European Economic and Monetary Union. This contributed to the return to a hard economic narrative in the EU agenda. This very instance, however, was not producing immediate negative effects for social rights and social protection per se. It is rather first and foremost the economic recession that aggravated the conditions of living of many, notably through employability prospects, with the most affected group being the youth.

Secondly, it comes as no surprise that the implementation of the austerity measures and instruments such as Fiscal Compact enforcing stringent budgetary and fiscal discipline resulted in drastic limitations to redistributive policies, notably but not exclusively in the debtor states. Moreover, some creditor states began to modify their policies vis-à-vis migrant workers introducing regulatory measures and taking administrative action which have effectively enforced concrete national policy on large-scale EU workers mobility. By way of example, limiting immigrants' access to social security (unemployment benefits, social housing, etc.), albeit not immediately in breach of EU law, may discourage some individuals from seeking a better professional perspective in the country taking such measures or even force migrant workers to return to their country of origin. As long as such measures are not creating less favourable labour conditions for migrant EU citizens than that of the host country nationals, Member States enjoy substantial freedom in shaping their social policies. This is the case of e.g. the German Law against abuse of social benefits enacted by German Bundestag on 7.11.2014, which was indirectly confirmed to be in conformity with the EU law by the judgement of the European Court of Justice

\footnotetext{
${ }^{3}$ See also http://eur-lex.europa.eu/legal-content/EN/TXT/?uri=URISERV:ai0023, (last accessed on 15.9.2015).
} 
of 11 November 2014 in case C-333/13 Dano/ Jobcenter Leipzig in which the Court ruled the exclusion of a migrant EU-citizen from social benefits of the host country as lawful insofar as the citizen did not have the status of a worker and therefore did not come under the scope of the relevant Article 24 of Directive 2004/38/EC 4 laying down the principle of equal treatment.

Thirdly, while some national governments seem to be reluctant to adjust their welfare systems to ever changing social and economic circumstances (such adjustment would mean, however, not only limiting entitlements to social assistance in times of crises, but also enhancing redistributive policy whenever the country's economy generates sufficient surplus), the austerity policy, which was imposed by the EU leaders and the International Monetary Fund as an initial response to the economic and sovereign debt crisis, may justly be criticized as excessive. It is only at the later stage of the crisis management that more attention was given to the need for Europe-wide social investment which, be it in private or public sector, is crucial in order to counter the increasing risk of poverty and boost the employment potential, notably in times of crisis. ${ }^{5}$ In particular, measures concerning the new missions of the European Social Fund (ESF) under Regulation (EU) No $1304 / 2013^{6}$ deserve attention in this regard. The ESF is tasked with improving employment opportunities, strengthening social inclusion, fighting poverty, promoting education, skills and life-long learning and developing active, comprehensive and sustainable inclusion policies in accordance with the missions entrusted to the ESF under Article 162 TFEU and thereby to contribute to economic, social and territorial cohesion (Article 174 TFEU). Since ESF funding is available through the Member States and regions, it is for the beneficiaries themselves (public administrations, workers' and employers' organisations, NGOs, charities, etc.) to make the best of the Fund's potential.

Moreover, in 2014 the European Social Policy Network (ESPN) was established with a view to providing the European Commission with independent information, analysis and expertise on social policies as well as assisting it in monitoring progress towards the EU social protection and social inclusion objectives as set out in the Europe 2020 strategy, notably addressing poverty and economic exclusion of around twenty million people. The ESPN is to provide the Commission with an overview of policies addressing major challenges in the areas of social protection (notably pensions, health care and long-term care) and social inclusion in EU and selected non-EU states, as well as the assessments whether the policies reflect the social investment approach. According to the report Social Investment in Europe drafted by the ESPN experts, only some EU Member States are maintaining an (often historically) well-established social investment approach to numerous social policy areas, whereas the majority have not made much progress and are still to develop such an explicit social investment approach (see Bouget et al., 2015).

In sum, measuring the real achievements against well-intentioned programmatic declarations, the overoptimistic ascertainment that, following the amendments introduced under the Treaty of Lisbon, the EU is now "premised on an integrated approach to economic and social politics, and pursues socio-economic integration as a holistic aim" (Schiek et al., 2015) has not been proved in practice, in particular under the unfavourable conditions flowing at present from the economic recession and austerity programme.

\footnotetext{
${ }^{4}$ Directive 2004/38/EC of the European Parliament and of the Council of 29 April 2004 on the right of citizens of the Union and their family members to move and reside freely within the territory of the Member States (O J 158/ 77), amending Regulation (EEC) No 1612/68 and repealing Directives 64/221/EEC, 68/360/EEC, 72/194/EEC, 73/148/EEC, 75/34/EEC, 75/35/EEC, 90/364/EEC, 90/365/EEC and 93/96/EEC.

${ }^{5}$ See to this effect the EESC-Opinion of 26/3/2014 on the impact of social investment on employment and public budgets; it calls on the Commission to provide for a more ambitious and longer-term policy roadmap to implement the social investment package by at least 2020 .

${ }^{6}$ Regulation (EU) No 1304/2013 of the European Parliament and of the Council of 17 December 2013 on the European Social Fund and repealing Council Regulation (EC) No 1081/2006, OJ L 347, 20.12.2013, pp. 470-486.
} 


\section{The need for revisiting the dominant economic narrative of the European project}

The powerlessness of the EU social dimension tends to be blamed on the embedded economic liberalism of the EU Internal Market (cf. e.g. Ashiagbor, 2013), one of the manifestations of which is that the Union has the normative power to establish the regulatory framework for its Single Market, while social policy remains by and large the competence of the Member States.

The EU's socio-economic model may indeed be considered as excessively liberal insofar as the EU Single Market policy-makers have all too long and all too often refused to take account of the impact of economic regulatory framework on the social issues, notably the legitimate social and labour rights. The fallacy of the alleged self-corrective capacity of the market economy has already been convincingly ascertained in economic research (cf. e.g. Krugman, 2012; Picketty, 2013; Stiglitz, 2015). In any case, a refusal to take account of social implications of a concrete economic policy is in itself, albeit somewhat paradoxically, a social "policy", or at least a concrete approach towards it. In other words, a laisser-faire policy is nothing else than an act of government (cf. Dworkin, 2014, p. 598).

Another aspect which merits to be put forth here is that the trajectory of the European integration process has been marked by tensions between EU Single Market economic freedoms and competition law on the one side, and social and labour rights on the other, which is mirrored in the rich case law of the European Court of Justice acting as a final arbiter of such conflicts. In particular social and labour rights of posted workers (see Directive 96/71/EC ${ }^{7}$ ) are negatively affected, which is demonstrated below on the basis of selected case law.

A landmark argumentation concerning the freedom of providing services was developed in the Case Rush Portuguesa ${ }^{8}$ where posting of workers is construed as the expression of the said freedom, any limitations of which would infringe on the employer's right to freely provide services. Whilst the Court subsequently ruled in favour of acknowledging restrictions to that right on grounds of the protection of workers' rights, notably their entitlement to a statutory minimum wage and related rights (Case Arblade \& Leloup) ${ }^{9}$, still the posted workers may not claim their rights to equal treatment themselves. ${ }^{10}$ It is rather for the host Member State to use its discretion and to impose on their employer an obligation to grant certain workers' rights (Schiek, 2015, p. 12), as was the case of Germany introducing on 1 January 2015 a new statutory minimum wage of 8.5 euro per hour, as provided for in the Minimum Wage Act. ${ }^{11}$

\footnotetext{
${ }^{7}$ Directive 96/71/EC of the European Parliament and of the Council of 16 December 1996 concerning the posting of workers in the framework of the provision of services, OJ L 18, 21.1.1997, pp. 1-6.

${ }^{8}$ Case 113/89 Rush Portuguesa (1990) ECR I-1417.

${ }^{9}$ See C-369/96 Arblade \& Leloup (1999) ECR I-8453 and other ECJ's case law, as cited by Schiek (2015, p. 12, note 69).

${ }^{10}$ On the protection of basic rights in the EU, see Haratsch and Schiffauer (2007).

${ }^{11}$ A certain controversy arose concerning the German Minimum Wage Act in question, since it applies also to international road haulage drivers transiting Germany. The question is whether Directive 96/71/EC on the posting of workers (see note xvii below) which seeks to cover posted workers with the minimum standards for working time, minimum pay, holidays, and health and safety in the host country should also apply to workers in the international road transport sector. In May 2015 the European Commission (EC) launched an infringement procedure against Germany, concerning the application of the Minimum Wage Act to the transport sector. As stated in the EC's Press release, the Commission, "whilst fully supporting the introduction of a minimum wage in Germany, (...) considers that the application of the Minimum Wage Act to all transport operations which touch German territory restricts the freedom to provide services and the free movement of goods in a disproportionate manner." Available at: http://europa.eu/rapid/press-release_IP-15-5003_en.htm (referred on 2.10.2015). On 16 June 2016 decided to proceed further and take legal action against Germany and France "owing to the consequences of the application of their respective minimum wage legislation to the road transport sector", see http://europa.eu/rapid/press-release_IP-16-2101_en.htm (accessed on 24.01.2017).
} 
The Laval case constitutes one of many examples where the ECJ orients its argumentation on safeguarding the Single Market accessibility ${ }^{12}$, thus finding even nondiscriminatory measures as potentially infringing on EU law if preventing or impeding access to the market, also by making the exercise of the commercial freedom to provide services granted by the Treaty less attractive (cf. Ashiagbor, 2013, p. 312). The Court held collective action as unlawful when constituting a restriction on the freedom to provide services within the meaning of Article 49 EC Treaty (currently Article 56 TFEU). ${ }^{13}$ In the concrete case Swedish trade unions had organised collective action against undertakings established in another Member State in order to force them to sign a collective agreement for the building sector which established more favourable terms and conditions of employment for posted workers. The Court considered that such action would make carrying out construction work in Sweden less attractive or more difficult for non-Swedish undertakings, and therefore in breach of the freedom to provide services guaranteed in the Single Market.

In the similar vein, in Viking ${ }^{14}$ the ECJ held that the right to strike could restrict businesses' freedom of establishment guaranteed under Article 43 EC Treaty (currently Article 49 TFEU). As regards the concrete background and substance of the case, Viking Line ABP operated a ship under a Finnish flag on the route between Estonia and Finland. In order to evade collective agreements with Finnish trade unions, and thus also cut the terms and conditions of work, it decided to register the ship in Estonia which is a low labour cost jurisdiction. The Finnish Seamen's Union (FSU), together with the International Transport Workers' Federation which FSU is affiliated to, decided to oppose such "reflagging for convenience" and planned industrial action instructing affiliates to boycott Viking's activities. The lawsuit before the UK courts where the International Transport Workers' Federation has its headquarters resulted in a reference for a preliminary ruling to the ECJ under Article 234 EC Treaty (currently Article 267 TFEU; pursuant to this Article the Court of Justice of the EU has an exclusive competence to interpret Treaty provisions). The Court ruled, however, that collective action which seeks to prevent ship owners from registering their vessels in a State other than that of which the beneficial owners of those vessels are nationals, typically to reduce wage costs ("re-flagging") constitutes a restriction of Viking's exercise of its right of freedom of establishment. The Court recognises that such restriction could be "justified by an overriding reason of public interest, such as the protection of workers", albeit it must be "suitable for ensuring the attainment of the legitimate objective pursued" and may not go "beyond what is necessary to achieve that objective". ${ }^{15}$ In practice it means that in case of conflict between businesses' economic freedoms within the EU Single Market and collective action seeking to protect workers' rights, the infringement on the former is to be presumed, while its exceptional justification may only be sought before national courts on a case-by-case basis.

While Laval and Viking cases are frequently seen as an attempt to reconcile social rights and economic freedoms, they are de facto oriented towards safeguarding the rules underpinning the Single Market, thus acting to the detriment of collective workers' rights. In response to this ECJ's jurisprudence and its potential future legacy, the European Trade Union Confederation (ETUC) advocated constitutionalisation of fundamental social rights at Union level by way of

\footnotetext{
${ }^{12}$ Case C-341/05 Laval (2007) ECR I-11767. In Case C-55/94, Gebhard (1995) ECR I-4165, para 37, the ECJ argued that it follows from its case law that "national measures liable to hinder or make less attractive the exercise of fundamental freedoms guaranteed by the Treaty must fulfil four conditions: they must be applied in a nondiscriminatory manner; they must be justified by imperative requirements in the general interest; they must be suitable for securing the attainment of the objective which they pursue; and they must not go beyond what is necessary in order to attain it (see Case C-19/92 Kraus v Land Baden-Wuerttemberg (1993) ECR I-1663, paragraph 32)".

${ }^{13}$ Case C-341/05 Laval (2007) ECR I-11767, paragraph 99.

${ }^{14}$ Case C-438/05 International Transport Workers' Federation and Finnish Seamen's Union v Viking Line ABP and Ö̈ Viking Line Eesti (2007), ECR I-10779.

${ }^{15}$ See paragraphs $73,86-90$, and in particular the closing sentence of the judgment.
} 
elevating them to a higher status than that of the economic freedoms and free competition rules. Such higher status would mean in practice that in case of conflict fundamental social rights would take precedence over economic and competition rules. ${ }^{16}$ In principle constitutionalisation of fundamental social rights would benefit greatly the advance of EU social dimension, albeit such automatism in conflict resolution between social and labour rights on the one hand and the economic freedoms on the other would seriously undermine the present foundations and functioning of the Single Market. A reasonable way forward could be seen in leaving the courts to analyse such conflicts on a case by case basis. Such an analysis seems to be required pursuant to Article 28 of the EU Charter of Fundamental Rights establishing the right of collective bargaining and action. However, as demonstrated above, the ECJ's case law to date does not necessarily strike a fair balance between social protection and respect of the Single Market rules. What is more, the adverse effects of the implementation of European internal market rules may not always be counterbalanced by national social protection measures. Ironically, the recent austerity policy imposed by EU decision-makers on some ailing Eurozone states has forced the latter to drastically reduce social security entitlements for their nationals. It is therefore arguable that EU market governance cannot be regarded as amounting to a reembedding of the social (Ashiagbor, 2013, p. 319). Hard law instruments in the field of EU social policy such as Directive 96/71/EC concerning the posting of workers ${ }^{17}$ may de facto contribute to "social dumping" of workers and commodification of labour.

As demonstrated by the Dano Case (see Section 2 above), welfare benefits of economically non-active EU citizens may be limited in a host Member State. This is in principle in accordance with EU primary and secondary law in force. Rights enjoyed under Union citizenship, including the right to move and reside freely within the territory of the EU Member States, are exercised in accordance with the conditions and limits specified by the EU Treaties and by the measures adopted thereunder (Article 20(2) TFEU). Article 4 of the Regulation (EC) No $883 / 2004^{18}$ provides for equal treatment of all EU citizens as well as stateless persons and refugees residing in a Member State, including members of their families, stipulating that such persons "shall enjoy the same benefits and be subject to the same obligations under the legislation of any Member State as the nationals thereof". However, Article 24(2) of the Directive 2004/38/EC ${ }^{19}$ introduces derogation from the principle of non-discrimination on grounds of nationality when it comes to entitlement to social assistance and maintenance aid. Consequently, by virtue of this Article the host Member State is freed from the obligation:

1. to confer entitlement to social assistance during the first three months of residence (where appropriate also for the longer period provided for in Article 14(4)(b)) or

2. to grant maintenance aid for studies and vocational training consisting in student grants or student loans to persons other than workers, self-employed persons, persons who retain such status and members of their families, prior to acquisition of the right of permanent residence by these persons.

The cited provisions are relevant with regard to Union citizens exercising their right of residence at the territory of one of Member States other than their country of origin and seeking social assistance and/ or maintenance aid. Pursuant to Article 6(1) the right of residence on the territory of another Member State for a period of up to three months is not subject to any conditions and is enjoyed both by EU citizens and their family members, even if they are not

\footnotetext{
${ }^{16}$ ETUC Proposal for a "Social Progress" Protocol of July 2009, Art. 3(1). The "social progress" clause was ultimately not endorsed in the EU Treaties.

${ }^{17}$ Directive 96/71/EC of the European Parliament and of the Council of 16 December 1996 concerning the posting of workers in the framework of the provision of services, OJ L 18, 21.1.1997, pp. 1-6.

${ }^{18}$ Regulation (EC) No 883/2004 of the European Parliament and the Council of 29 April 2004 on the coordination of social security systems (O J L 166/ 1).

${ }^{19}$ See supra note 4.
} 
nationals of a Member State (Article 6(2)). The right of residence for a period longer than three months is granted to workers, self-employed, persons following a course of study or vocational training and those who have comprehensive sickness insurance cover in the host Member State as well as sufficient resources for themselves and their family members so as not to become a "burden on the social assistance system of the host Member State during their period of residence" (Article 7(1)(b), emphasis by the author).

This state of the art regarding the EU law in force and the ECJ's stance on equal treatment of Union citizens is frequently criticized as contradictory, since only economically active individuals are able to exercise it fully. This renders EU citizenship as an "empty shell" (Schiek, 2015, p. 12), in particular when assessed through the idealistic prism of "transnational social citizenship" that would be based on transnational solidarity and give access to transnational social rights (cf. ibid.).

The chosen policies for implementing the European Internal Market and its inherent freedoms have thus contributed to undermining the social dimension of both the EU and its Member States. Under the prevailing paradigm of free market competition social intervention, if at all legally viable, is very much limited. However, any tentative to engrave the embedded EU economic liberalism into marble could be dangerous insofar as it would entirely put into question the EU's vocation to ensure peace and welfare, its geopolitical role in the promotion of world-wide social justice, and thus its very legitimacy. In any case, the aspiration to create a continent-wide political entity without internal borders is as such a noble project. Even if conceived as pursuing by and large economic objectives, it does not immediately undermine its added value. Everybody may benefit from the capitalist economy providing the profits are appropriately distributed (Hösle, 1997, p. 865).

It seems that the EU leaders begin to be aware of past mistakes and restrain distorting liberal practices and abuses by the privileged. By way of example, the European regulators targeted bonuses paid to bankers by means of Directive 2013/36/EU imposing a cap forcing banks to limit bonuses to $100 \%$ of the salary, with an option to increase it to $200 \%$ subject to shareholders' approval. ${ }^{20}$ More recent EU activity in connection with the disclosure of doubtful tax privileges granted in the past years by the governments of several Member States and notably Luxembourg, consisted in putting under supervision special tax agreements enjoyed by big corporations with selected EU States so as to curtail tax evasion practices. Most important and desirable was the reform of the rules for the banking sector, notably with regard to adequacy of capital maintained by banks compared to the risk incurred as well as countering excessive risk taking (stricter rules were introduced in 2013 by the so called CRR/ CRD IV legislative package $^{21}$ ). While the relevance of this reform for social policy may not be self-explanatory, it should be kept in mind that, in the course of the financial crisis, bail-outs were performed on a regular basis at the expense of the EU Member States' budgets to shore up non-viable banks, thus directly limiting the margins of manoeuvre for national governments in the field of social policy.

The EU has by no means exhausted its powers to develop the social dimension of its single market. Still, to that end it must, in cooperation with the Member States, implement measures which take account of the diverse forms of national practices, notably with respect to contractual relations, and the need to maintain the competitiveness of the Union's economy

\footnotetext{
${ }^{20}$ See Article 94(1)(g of Directive 2013/36/EU of the European Parliament and of the Council of 26 June 2013 on access to the activity of credit institutions and the prudential supervision of credit institutions and investment firms, OJ L 176, p. 338.

${ }^{21}$ Regulation (EU) No 575/2013 of the European Parliament and of the Council of 26 June 2013 on prudential requirements for credit institutions and investment firms and amending Regulation (EU) No 648/2012, OJ L 176, 27.6.2013, pp. 1-337; Directive 2013/36/EU of the European Parliament and of the Council of 26 June 2013 on access to the activity of credit institutions and the prudential supervision of credit institutions and investment firms, OJ L 176, p. 338.
} 
(Article 151 TFEU). It follows from the cited provision that, since the development and implementation of social policies remains principally the responsibility of Member States, under the EU law currently in force the Union has but a limited margin of manoeuvre regarding a direct impact on the well-being of individual Union citizens. It is also defendable that Member States are better predisposed to implement social security measures. Therefore, revisiting the dominant economic narrative of the European project with a view to an improved social balance is only conceivable on the condition of political will and commitment at both national and Union level.

\section{Regulation vs. Coordination: diagnosing the ailments of the EU's social policy}

One of the alleged weaknesses of the EU social policy is that it is frequently limited to soft measures and objectives, whereas hard law provides for the implementation of the European Internal Market rules. The main point that needs to be highlighted in the present contribution relates to the complexity of putting social policy into effect at Union level. This complexity presupposes a variety of factors which contribute to and determine the overall functioning (or failing) of the EU social dimension. There may not, therefore, be a sole "villain" responsible for the ailing of the EU social policy.

A precondition for remedying an ailment is an appropriate diagnosis. The qualitative (substantive) change in the EU social dimension may not be effected by a mere change of discourse in the Treaties. We could also state that it is not the very name that makes a policy, but the policy makes its very name. Social market economy does not emerge by the very fact of being referred to as social. Also the modes of materialisation of the social in the market economy context tend to differ, of which the EU states such as Poland and Germany are telling examples. While both states acclaim social market economy, only Germany for quite some time could serve as a social welfare model. In recent years, however, even this country experienced tangible dismantling of social entitlements allegedly aimed to keep up the country's productive competitiveness in the face of emerging economic powers outside Europe.

On the other hand, as argued earlier, any capitalist system is also a socio-economic system. If not construed as unavoidable antagonist phenomena, the inherent conflict of interest between the Single Market and social policy of the EU may, however, be considered as an opportunity for a constructive dialectic whereby best practices are being established to balance the legitimate interests and expectations of both economic and social dimension of European space (cf. Dietze, 2009, p. 232f, Bitumi (2017, p. 1) speaks about "socially embedded capitalism"). As demonstrated by the Social Investment Package (SIP) ${ }^{22}$ adopted by the European Commission in February 2013, this approach is not necessarily unrealistic, as welldesigned social policies tangibly contribute to economic stability and sustainable development.

Coming back to the implementation of social policy, although it is part of the shared competences between the Union and its Member States, the competences of the EU remain very modest since, in accordance with the principle of subsidiarity (Article 5(3) TEU), its role in this area is limited to supporting and complementing the activities of the Member States (Article 153 TFEU). Majority of EU social policy measures are adopted in accordance with the ordinary legislative procedure under Article 153(2) TFEU, i.e. the adoption of such legislation requires deliberating on a proposal by the EU-Commission, the European Parliament and the Council (where the governments of all EU-Member States are represented), at the end of which process all the mentioned institutions must agree on the proposal's wording. However, certain measures are adopted by the Council alone, acting unanimously in accordance with a special legislative

\footnotetext{
${ }^{22}$ See European Commission Communication entitled "Towards Social Investment for Growth and Cohesion including implementing the European Social Fund 2014-2020". Available at: http://eurlex.europa.eu/LexUriServ/LexUriServ.do?uri=COM:2013:0083:FIN:EN:PDF (referred on 20/02/2017).
} 
procedure, after consulting the European Parliament (EP), the Economic and Social Committee and the Committee of Regions. The Treaty of Lisbon maintains the so- called specific bridging clause which enables the Council to decide unanimously to apply the ordinary legislative procedure in the following fields:

- protection of workers where their employment contract is terminated,

- representation and collective defence of the interests of workers and employers, including co-determination, subject to limitations under Article 153(5), ${ }^{23}$

- conditions of employment for third-country nationals legally residing in EU territory. In all policy areas under Article 153 TFEU except the fight against social exclusion and the modernisation of social protection systems, the EP and the Council may adopt directives laying down minimum requirements for gradual implementation. Such directives, however, "shall avoid imposing administrative, financial and legal constraints in a way which would hold back the creation and development of small and medium-sized undertakings" (Article 153(2)(b) TFEU).

Social policy areas which fall within the competence of Member States (notably employment, social protection and social inclusion, education, youth and training), are subject to the open method of coordination (OMC). This is a method of intergovernmental cooperation between Member States with the aim to orientate national policies towards certain common objectives. The results of such efforts of OMC are laid down in "soft law" measures such as guidelines, statistics, benchmarking, sharing of best practices and periodic evaluation, which politically "bind" Member States in varying degrees, while not being of a normative character. ${ }^{24}$ Member States first jointly identify and set objectives to be achieved, which are subsequently endorsed by the Council. The Commission has primarily a monitoring role.

The OMC tends to be underestimated due to its reliance on soft measures and the absence of sanctions for laggards. The method's effectiveness rests on peer pressure, with Member States generally trying to avoid being pointed to as the worst in a given policy area. It should also be noted here that social policy is not the sole area subject to coordination. Even if EU/Eurozone reform measures like the Fiscal Compact and the regulations implementing budgetary discipline (six-pack and two-pack) somewhat evened out the pre-crisis asymmetries between binding EU regulation of monetary policy and mere coordination in economic policy, the conduct of the latter continues to be effected by and large by means of coordination. This may be observed, for instance, in the context of the European Semester (i.e. the implementation of the EU's economic governance in an annual cycle of policy guidance and surveillance). It is noteworthy that the Country-Specific Recommendations (CSRs) issued by the European Commission are expanding considerably in social scope from year to year, which phenomenon is referred to in literature as "socialising" the European Semester (Zeitlin and Vanhercke, 2015).

The positive impact of the OMC may also be seen in that the EU-Commission receives a say where the Union itself has no or only limited legislative powers. It may, for instance, take a form of country-specific recommendations for employment policy, health systems, etc. Given that the Commission has at its disposal a pool of experts constantly monitoring and evaluating the social policy development and needs, such recommendations may prove highly relevant with regard not only to the promotion of social and labour rights, but also to the achievement of sustainable economic development. In sum, even though social policies are determined nationally, the Union impacts on them in a variety of ways, thus amounting to the most important external source of influence (Kettunen and Wolff, 2011, p. 156).

\footnotetext{
${ }^{23}$ The provisions in question do not apply to such salient areas as pay, right of association, the right to strike or the right to impose lock-outs.

${ }^{24}$ By way of example, in the frame of Lisbon Strategy, the OMC requires Member States to work out and submit to the Commission national reform plans.
} 
Turning back to the ailments of the EU social policy, our core argument here is that they should not be simply ascribed to the fact that the implementation of the EU social policy rests by and large on soft measures (for an opposing view, see e.g. Falkner, 2006). A shift towards hard law in social policy at EU-level by increasing the Union's legislative powers would not necessarily lead to positive ramifications, since the use which can be made of such powers very much depends on the political orientations prevailing in its legislative institutions. The aspect which should, however, be taken into account is that of even a deeper-rooted conflict than that relating to social and economic policies, namely lying at the very foundations of the Union. From the perspective of national constitutional law and legal doctrine, the European Union does not possess the competence to decide on its own competence (Kompetenz-Kompetenz). Pursuant to that rule, any exercise of supranational competences takes place on the basis of the principle of conferral (Article 5(2) TEU), with the Member States remaining the unquestionable Masters of the Treaties. ${ }^{25}$ Likewise, no EU secondary legislation may be adopted unless endorsed by the Council, the latter typically representing EU Member States interests. Consequently, even if combating unemployment constitutes an objective which should be pursued concomitantly at national and EU level, as long as no specific power in the field of employment policy has been conferred to the Union, it is for the Member States to adopt relevant measures, e.g. that of stricter employment protection legislation (EPL). Factors such as stricter EPL for regular contracts or more generous benefits in terms of volume and/or time counteract the effects of economic fluctuations, which appear to constitute the most important element influencing the employment of low-skilled individuals. On the contrary, and somewhat against common conviction, less restrictive EPL seems to have adverse consequences for the employability of low-educated workers who find it difficult to adapt and re-enter the structurally changed labour market (cf. e.g. Abrassart, 2015, p. 236f). ${ }^{26}$

To conclude, the Union might be deficient in instruments and legitimacy to address all contemporary social problems of Union citizens, albeit it must act to counter or at least outweigh the subordination of society to economy if it is to survive as a viable political project. At the same time, any considerable advance of social and labour rights as well as social justice principle on the European continent is dependent on the joint efforts and commitment of both nation states and the Union, otherwise justice will remain a "formula for contingency" (Luhmann, 2008, p. 211).

\section{Conclusions}

The legal framework for EU social policy draws strongly from the past, mirrors sincere efforts to reflect the present, but does it pave the Union's way for the future? It is arguable that the political majorities prevailing in the Union's institutions up to now allowed only a very restricted use of the Union's powers to develop the social dimension of its Single Market. Sociologists consider the normative stabilisation of expectations as one of the functions of law (Luhmann, 2008, p. 473). The potential of a common European social policy in providing the foundations for European political awareness was in principle rightly identified (cf. e.g. Pliakos, 1993, p. 216), even before it was fully endorsed in the Treaties. The social justice narrative

\footnotetext{
${ }^{25}$ See the judgment of the Federal Constitutional Court of Germany on the Lisbon Treaty, paragraphs 231-233; the text of the judgment is available in English at:

http://www.bundesverfassungsgericht.de/SharedDocs/Entscheidungen/EN/2009/06/es20090630_2bve000208en. html (referred on 21/02/2017). The German Court holds that only "controlled and responsible transfer" of sovereign powers to the transnational level Is possible under national constitutional law (see ibid., cf. also points 233 and 239).

${ }^{26}$ Abrassart (2015, p. 232ff) provides evidence inter alia in favour of more generous benefits, which - contrary to the common conviction - have a positive long-term effect on the employment rates of the low-educated individuals allowing them enough time to look for jobs available on the market which better match their particular skills.
} 
disseminated at the transnational level has awakened expectations among the citizenry which up to now may hardly be satisfied, as the ambitious social policy objectives which the Union commits itself to promote are not yet reflected in a European social model in normative terms. Through this critical lens the EU social policy may therefore be assessed as failing, since "for an actor which is supposed to embody a community of equals striving for ever greater convergence, inequality represents a major challenge that may possibly lead to its demise" (Zielonka, 2015, p. 19). However, is the transnational (European) level to blame for limited progress in the building up of the Social Europe project?

EU policy must above all be coherent and not unnecessarily undermine positive achievements of national social security models. In other words, EU policy risks to contradict itself when imposing on Member States uniformly tailored austerity measures that cannot be implemented but by cruel cuts in the social security system. Still, given that the tools of social policy rest with the Member States, this is where the qualitative change must occur first. The reflection paper on developing the social dimension of Europe which on 1st March 2017 was announced by Commission President Juncker is therefore expected with strong interest.

Europe is and will in all likelihood be facing ever more complex social problems, which arguably may only be efficiently addressed if it stays economically competitive and attractive in the international arena. As to the aim of strengthening the weight of social policy concerns vis-à-vis the interests of free markets, it is neither possible, nor desirable to achieve it only through quantitative increase of hard law. Instead a paradigm shift operating pressure on the EU Member States to adapt their standards of social welfare to a higher level would appear as promising. Smart EU-regulation should not be limited to protecting workers and consumers against any undesirable output of market liberalism. It should also promote social and economic policies as mutually interdependent and reinforcing. Article 7 TFEU calls on the Union to ensure consistency of its policies. This means to even out any inequality of the tools that the policies in question operate with and to fully implement in all measures adopted at EU level objectives such as the guarantee of adequate social protection and the fight against social exclusion, as stipulated in Article 9 TFEU. This would require that economic and financial policies, both at national and European level, better take into account social protection and social inclusion objectives. Even if modest, but fully realistic. The institutional assets for doing so are at hand. Whether and how they will be used depends on consciousness in society and will in the political institutions, both on national and EU level.

\section{References}

Abrassart, A. (2015). Low-skill jobs or jobs for low-skilled workers? An analysis of the institutional determinants of the employment rates of low-educated workers in 19 OECD countries, 1997-2010. Journal of European Social Policy, 25(2), pp. 225-241.

Ashiagbor, D. (2013). Unravelling the Embedded Liberal Bargain: Labour and Social Welfare Law in the Context of EU Market Integration. European Law Journal, 19(3), pp. 303324.

Bouget et al. (2015). Social Investment in Europe. A study of national policies 2015, European Social Policy Network, European Commission, Directorate-General for Employment, Social Affairs and Inclusion.

Bitumi, A. (2017). Narrating Social Europe. The Search for Progress in the "Age of Delors". Notre Europe Policy Paper, 23 January 2017, p. 1-20.

Den Hertog, L. (2016). Money Talks. Mapping the funding for EU external migration policy. CEPS Paper in Liberty and Security in Europe No. 95/ November 2016. p.1-56, available at 
https://www.ceps.eu/system/files/LSE\%20No\%2095\%20LdH\%20Mapping\%20Fundin g\%20final.pdf, (referred on 20/02/2017).

Dietze, Ch. (2009). Das Projekt Europa in der Dialektik von freiem Markt und sozialer Gerechtigkeit (The European Project in the Discourse from Free Market to Social Justice), Berlin: BWV.

Dworkin, R. (2014). Gerechtigkeit für Igel (Justice for Hedgehogs). Suhrkamp Taschenbuch Wissenschaft, Berlin.

European Commission Communication entitled "Towards Social Investment for Growth and Cohesion - including implementing the European Social Fund 2014-2020". Available at: http://eur-lex.europa.eu/LexUriServ/LexUriServ.do?uri=COM:2013:0083:FIN:EN:PDF (referred on 20/02/2017).

European Commission White Paper on the Future of Europe. Reflections and Scenarios for the EU27 by 2025, Brussels, $1^{\text {st }}$ March 2017.

Falkner, G. (2006). Forms of governance in European Union social policy: Continuity and/or change? International Social Security Review, 59(2), pp. 77-103.

Haratsch, A, and Schiffauer, P. (2007). Grundrechtsschutz in der Europäischen Union (The Protection of Basic Rights in the European Union). Berlin: Berliner WissenschaftsVerlag.

Hösle, V. (1997). Moral und Politik. Grundlagen einer politischen Ethik für das 21. Jahrhundert (Morality and Politics. Foundations of Political Ethics for the 21st Century). C.H. Beck, München.

Kettunen, P., Wolff, C. (2010). Europeanisation through the Back Door: EU Social Policy and the Member States. Politička misao, 47(5), pp. 144-158.

Krugman, P. (2012). Sortez-nous de cette crise ... maintenant! French edition, Flammarion.

Luhmann, N. (2008). Law as a Social System. Oxford and New York: Oxford University Press (original book in German 1993).

Lenaerts, K. (2011). European Union Citizenship, National Welfare Systems and Social Solidarity. Jurisprudencija, 18(2), pp. 397-422.

Piketty, Th. (2013). Le capital au XXIe siècle (Capital in the twenty-first century). Seuil, Paris.

Pliakos, A. D. (1993). La nature juridique de l'Union européenne (The legal nature of the European Union). RTDE 29(2), pp. 187-223.

Schiek, D. (2015). Perspectives on social citizenship in the EU - from status positivus to status socialis activus via two forms of transnational solidarity. CETLS Online Paper Series, 4(1), pp. 1-27.

Schiek, D. et al. (2015). EU Social and Labour Rights and EU Internal Market Law, Study for the European Parliament's Committee on Employment Affairs (EMPL).

Schraad-Tischler, D. and Kroll, Ch. (2014). Social Justice in the EU - A Cross-national Comparison. Social Inclusion Monitor Europe (SIM) - Index Report, pp. 1-114.

Stiglitz, J. E. (2015). Cena nierówności. W jaki sposób dzisiejsze podziały społeczne zagrażaja naszej przyszłości? Warszawa: Wydawnictwo Krytyki Politycznej.

Zeitlin, J., and Vanhercke, B. (2015). Economic governance in Europe 2020: socialising the European Semester against the odds?, in: D. Natali and B. Vanhercke, Social policy in the European Union: state of play 2015, European Trade Union Institute (ETUI) and European Social Observatory (OSE), pp. 65-95.

Zielonka, J. (2015). Why the EU Should Focus On realistic Social Policy Projects. Social Europe Journal, 8(2), pp. 19-21. 


\section{Relevant Legal Acts}

Council Directive 75/117/EEC and Council Directive 76/207/EEC, recast by Directive 2006/54/EC of the European Parliament and of the Council of 5 July 2006 on the implementation of the principle of equal opportunities and equal treatment of men and women in matters of employment and occupation, OJ L 204, 26.7.2006, pp. 23-36.

Council Directive 75/129/EEC, Council Directive 77/187/EEC and Council Directive 80/987/EEC, respectively, later amended and / or consolidated.

Council Directive 75/117/EEC and Council Directive 76/207/EEC, recast by Directive 2006/54/EC of the European Parliament and of the Council of 5 July 2006 on the implementation of the principle of equal opportunities and equal treatment of men and women in matters of employment and occupation, OJ L 204, 26.7.2006, pp. 23-36.

Directive 2013/36/EU of the European Parliament and of the Council of 26 June 2013 on access to the activity of credit institutions and the prudential supervision of credit institutions and investment firms, OJ L 176, p. 338.

Directive 96/71/EC of the European Parliament and of the Council of 16 December 1996 concerning the posting of workers in the framework of the provision of services, OJ L 18, 21.1.1997, pp. 1-6.

Directive 2004/38/EC of the European Parliament and of the Council of 29 April 2004 on the right of citizens of the Union and their family members to move and reside freely within the territory of the Member States (O J 158/77), amending Regulation (EEC) No 1612/68 and repealing Directives 64/221/EEC, 68/360/EEC, 72/194/EEC, 73/148/EEC, 75/34/EEC, 75/35/EEC, 90/364/EEC, 90/365/EEC and 93/96/EEC.

Regulation (EU) No 575/2013 of the European Parliament and of the Council of 26 June 2013 on prudential requirements for credit institutions and investment firms and amending Regulation (EU) No 648/2012, OJ L 176, 27.6.2013, pp. 1-337.

Regulation (EC) No 883/2004 of the European Parliament and the Council of 29 April 2004 on the coordination of social security systems O J L 166, p. 1.

Regulation (EU) No 1304/2013 of the European Parliament and of the Council of 17 December 2013 on the European Social Fund and repealing Council Regulation (EC) No 1081/2006, OJ L 347, 20.12.2013, pp. 470-486.

\section{Case Law}

Bundesverfassungsgericht, Judgment of 30 June 2009 - 2 BvE 2/08, the text of the judgment is available in English at:

http://www.bundesverfassungsgericht.de/SharedDocs/Entscheidungen/EN/2009/06/es200906 30_2bve000208en.html (referred on 21/02/2017).

Case C-438/05 International Transport Workers' Federation and Finnish Seamen's Union v Viking Line ABP and OÜ Viking Line Eesti (2007), ECR I-10779.

Case C-341/05 Laval (2007) ECR I-11767.

Case C-19/92 Kraus v Land Baden-Wuerttemberg (1993) ECR I-1663.

Case C-369/96 Arblade \& Leloup (1999) ECR I-8453.

Case 113/89 Rush Portuguesa (1990) ECR I-1417 Case 113/89 Rush Portuguesa (1990) ECR I-1417. 